\title{
ThHog1 controls the hyperosmotic stress response in Trichoderma harzianum
}

Correspondence

Jesús Delgado-Jarana

jesus.delgado@ibvf.csic.es

Received 29 November 2005

Revised 30 January 2006

Accepted 8 February 2006

\author{
Jesús Delgado-Jarana, ${ }^{1}$ Sonia Sousa, ${ }^{1}$ Fran González, ${ }^{2}$ Manuel Rey² \\ and Antonio Llobell ${ }^{1}$ \\ ${ }^{1}$ Instituto de Bioquímica Vegetal y Fotosíntesis, Universidad de Sevilla/CSIC, CIC Isla de la \\ Cartuja, Sevilla, Spain \\ ${ }^{2}$ Newbiotechnic SA, Parque Industrial Bollullos de la Mitación, Sevilla, Spain
}

\section{INTRODUCTION}

Eukaryotes use different mitogen-activated protein kinase (MAPK) cascades to control the gene expression required by a plethora of biological processes (Gustin et al., 1998). Changes in the environment that provoke stress are sensed via a MAPK member of the family of stress-activated protein kinases (SAPKs) (Roux \& Blenis, 2004). In yeasts, the MAPK that controls stress response is Hog1 (Hohmann, 2002), and homologue proteins have been also found in other fungi such as Schizosaccharomyces pombe (Degols et al., 1996), Aspergillus nidulans (Han \& Prade, 2002; Kawasaki et al., 2002), Cryptococcus neoformans (Bahn et al., 2005), Magnaporthe grisea (Dixon et al., 1999), Candida albicans (AlonsoMonge et al., 2003), Cryphonectria parasitica (Park et al., 2004), Neurospora crassa (Zhang et al., 2002) and Colletotrichum lagenarium (Kojima et al., 2004). In humans, a related group of MAPKs with three different families (SAPK,

Abbreviations: CsA, cyclosporin A; DAPI, 4',6-diamidino-2-phenylindole; EST, expressed sequence tag; MAPK, mitogen activated protein kinase.
ERK and p38) also controls stress response and inflammation (Kyriakis \& Avruch, 2001).

To adapt to stress conditions, different strategies involving diverse regulatory mechanisms have been developed by fungi. In Saccharomyces cerevisiae, Hogl is activated by hyperosmotic shock (Hohmann, 2002), heat (Winkler et al., 2002) and citric acid (Lawrence et al., 2004). Moreover, Hog1 and other proteins are required to develop stress resistance (Bilsland et al., 2004). Styl, the Hog1 homologue in fission yeast, is activated when cells are exposed to a wide variety of stress conditions (Degols et al., 1996; Shieh et al., 1997) and stress genes are mostly controlled by Sty1 (Chen et al., 2003). As a result, in S. cerevisiae, hog $1 \Delta$ mutants are mainly impaired in the high-osmolarity stress response, and the oxidative stress response in some conditions (Bilsland et al., 2004). In fission yeast and Aspergillus nidulans, MAPK mutants are highly sensitive to high osmolarity, heat shock and oxidative stress (Kawasaki et al., 2002). The set of genes that is highly induced under different stress conditions has defined the common environmental stress response, CESR (Alonso-Monge et al., 2003; Causton et al., 2001; Chen et al., 
2003; Gasch et al., 2000; Rep et al., 2000; Smith et al., 2004). Cells exposed to a low dose of one stress factor become resistant to a low dose of a second unrelated stress. This phenomenon is called cross-resistance (Hohmann \& Mager, 1997).

The mechanism by which Hog1 activates the stress response has been thoroughly studied in yeasts (Hohmann, 2002). Two osmosensors, localized in the plasma membrane, transduce the signal perceived through two different MAPKKK inducing the phosphorylation of the MAPKK Pbs2, and, subsequently, Hog1. Emerging cues point to a similar situation in other fungi (Han \& Prade, 2002; Motoyama et al., 2005).

Trichoderma has been identified as a fungal genus with a high ability to colonize diverse environments. This versatile genus antagonizes other fungal cells (mycoparasitism), which is the basis for its use in agriculture to control fungal plant pathogens. Furthermore, increasing evidences point to a symbiotic mycorrhiza-like relationship of Trichoderma with plants (Harman et al., 2004; Lu et al., 2004). Finally, a variety of hydrolytic enzymes are used by Trichoderma to obtain nutrients from soil and plant material (Kubicek \& Penttila, 1998), which makes this genus a unique source to identify polymer-degrading enzymes with industrial value (Penttila, 1998). Elucidating the role of the Hog1 protein homologue in T. harzianum may help to understand how this fungus adapts to stress and a changing environment and develops its parasitic, symbiotic and saprophytic lifestyles.

\section{METHODS}

Strains, media, growth and transformation conditions. Trichoderma harzianum CECT 2413 was obtained from the Colección Española de Cultivos Tipo (Burjasot, Valencia, Spain). Colletotrichum acutatum and Phoma betae were provided by Dr E. Monte (University of Salamanca, Salamanca, Spain). Yeasts strains were kindly provided by Dr G. Yaakob (Hebrew University of Jerusalem, Israel). T. harzianum was maintained on potato dextrose agar $(2 \%$, $\mathrm{w} / \mathrm{v}$, commercial dehydrated potato flakes; $2 \%, \mathrm{w} / \mathrm{v}$, glucose; $2 \%$, $\mathrm{w} / \mathrm{v}$, agar). Plates for drop assay were prepared using minimal medium (MM) supplemented with $2 \%(\mathrm{w} / \mathrm{v})$ glucose and $0.5 \%$ $(\mathrm{w} / \mathrm{v})$ ammonium sulphate (Penttila et al., 1987). When indicated, $10 \mu \mathrm{g}$ cyclosporin $\mathrm{A} \mathrm{ml}^{-1}$ (Calbiochem), $1 \cdot 2 \mathrm{M}$ sorbitol, $1 \mathrm{M} \mathrm{NaCl}$, $10 \mathrm{mM} \mathrm{H}_{2} \mathrm{O}_{2}, 40 \mathrm{mM} \mathrm{CuSO} 4$ or $5 \mathrm{mg}$ L-tryptophan $\mathrm{ml}^{-1}$ was added. In some instances, carbon, nitrogen and phosphorus depletion conditions were used. In $1 \%(\mathrm{w} / \mathrm{v})$ chitin-containing medium, glucose was not added. When indicated, the $\mathrm{pH}$ of $\mathrm{MM}$ was adjusted to 10 . Plates were incubated at $30^{\circ} \mathrm{C}$. Drop assays were performed using $3 \mu \mathrm{l}$ drops containing $2 \times 10^{7}$ spores $\mathrm{ml}^{-1}$ and tenfold serial dilutions. T. harzianum was transformed using the PEG-based protocol (Penttila et al., 1987). For antifungal ability tests, fungal strains were previously grown for 7 days on PDA plates. Plugs $6 \mathrm{~mm}$ in diameter were inoculated on fresh PDA plates and incubated at $25^{\circ} \mathrm{C}$ for 7 days to observe overgrowth.

Mycelia for both Northern and array experiments and the preparation of intracellular extracts were obtained in two steps as follows. One hundred millilitres of TSB medium (Tryptic Soy Broth, Merck) was inoculated with a spore suspension (final concentration: $10^{6}$ spores $\mathrm{ml}^{-1}$ ) and incubated for $16 \mathrm{~h}$. Mycelia were filtered, and used to reinoculate fresh $\mathrm{MM}$ as described for each experiment. Unless otherwise indicated, $2 \%(\mathrm{w} / \mathrm{v})$ glucose and $0.5 \%(\mathrm{w} / \mathrm{v})$ ammonium sulphate were used as carbon and nitrogen sources. Liquid cultures were grown at $28^{\circ} \mathrm{C}$ and 200 r.p.m. in a rotary shaker.

Vectors and strains. Cloning of the T. harzianum hog1 gene was performed as follows: The ESTs (expressed sequence tags) database from $T$. harzianum developed within the TrichoEST project (www.trichoderma.org) was screened. EST L02T34P026R02431 contained the complete ORF from the hog1 gene; it was fully sequenced, and used as a probe to screen a genomic library prepared in $\lambda$ GEM11. Genome walking was performed to complete promoter sequencing using the Genome Walker kit (Clontech). The specific primer 5'-CTCGTAAGGATGGAGGATCGCAGCGGG-3' and commercial adaptor primer were used, and the band obtained was re-amplified using the nested specific primer $5^{\prime}$-GGATCGCAGCGGGAGGATACGAGTAAA- $3^{\prime}$. One contig of $4 \cdot 2 \mathrm{kbp}$ was obtained and fully sequenced.

Yeast phenotypic assays were carried out using a $h \circ g 1 \Delta$ strain of S. cerevisiae (MATa his3 leu2 ura3 hog1:: TRP ade8) kindly provided by Dr G. Yaakov, Department of Biological Chemistry, The Institute of Life Sciences, The Hebrew University of Jerusalem (Bell et al., 2001), as well as pES86HOG1 and pES86HOG1 ${ }^{\mathrm{F} 318 \mathrm{~S}}$ (with yeast HOG1 wildtype and mutant allele, respectively). This vector contains the ura3 marker and $a d h 1$ promoter. To clone the hogl gene from T. harzianum into pES86 vector, the hog1 cDNA was amplified using primers 5'-GGAAGCTTCATCACGAGTCAAATCGATCC-3' and 3'-GGGCGGCCGCTCCGCTGTTCCATTCATTCAA-5', and cloned in pES86 using HindIII and NotI enzymes (sites underlined). Using the resulting pES86-hog1 as a template, pES86- $\log ^{\mathrm{F} 315 \mathrm{~S}}$ was obtained using the QuickChange Mutagenesis kit (Stratagene). Primers used in mutagenesis were $5^{\prime}$-GCCGATGAGAAGTCTGACTGGAGCTTTA-3' and its complementary. Mutation was checked by sequencing. Transformation and standard techniques used in yeast were performed as described by Sambrook \& Russell (2001). Stress sensitivity of yeasts was assayed in appropriately supplemented YNB medium.

Vectors for T. harzianum transformation were derived from pLMRS3 (Mach et al., 1994). The genomic clone of hogl was amplified using primers 5'-GGTCTAGAGCCATCACGAGTCAAATCGATC-3' and 5' GGATGCATAGGTCCGCTGTTCCATTCATTC-3', which introduced $X b a \mathrm{I}$ and $N$ siI sites, respectively (underlined). Using the resulting pLMRS3-hog1 as a template, pLMRS3-hog $1^{\mathrm{F} 315 \mathrm{~S}}$ was obtained using the QuickChange Mutagenesis kit (Stratagene) with primer 5'-GCCGATGAGAAGTCTGACTGGAGCTTTA-3' and its complementary. Mutation was checked by sequencing. T. harzianum CECT 2413 was transformed; one strain which had integrated only one copy of the vector was used in further experiments and named FS12, although other strains obtained in the same transformation experiment showed identical results.

Silencing was obtained using a hairpin construct as follows. pSIL vector constructed by S. Sousa (Sousa, 2004) was used. This vector contains a strong promoter from T. harzianum (tss1), an intron sequence and the $c b h 2$ terminator. The final construct showed two direct inverted sequences of hog1 separated by the intron. A 545 bp hog1 fragment including the $5^{\prime}$ end of the ORF was amplified using primers 5'-GGAAGCTTACTAGTAGATCTTTGGCACCACGTTC-3' and 5'GGGAATTCGGATCCGCTGTAGAAGGCGATGTTAG-3', which introduced HindIII and SpeI sites and EcoRI and BamHI sites, respectively (underlined and italicized). The fragment in direct orientation was cloned using SpeI and BamHI sites, whereas an inverted repeat was introduced using EcoRI and HindIII sites. This vector, named pSILHOG, was used to transform T. harzianum CECT 2413. One of the transformed strains only showed one copy of the vector and was named SHM1. 


\section{Array experiments}

Macro-array building. The DNA to be spotted was obtained by PCR using universal primers from the library vector and cDNA clones isolated from libraries prepared from T. harzianum CECT 2413 (www.trichoderma.org). Those libraries were obtained from mycelia growing in different cultures which covered a wide range of conditions (glucose or chitin as carbon sources, nitrogen and carbon starvation, fungal cell walls, plant cell walls, and acid $\mathrm{pH}$ ). One-hundredmicrolitre PCRs were performed in 96-well microtitre plates, with standard amplification parameters. One microlitre of the PCR products was separated on an agarose gel to check the product quality and quantity. Before spotting, the DNA was denatured in $50 \%$ DMSO. The DNA was spotted with a BIOMEK 2000 robot (Beckman) on Hybond-N + membranes (Amersham Biosciences). After deposition, DNA was cross-linked to the membranes by UV radiation $(125 \mathrm{~mJ})$ in a Vilber-Lourmat cross-linker. Membranes were stored at room temperature until use. A set of filters was prepared containing all unique sequences found at the time of the analysis (M. Rey \& F. González, unpublished). Twenty-six microtitre plates containing 96 clones each (2496 total spots) were spotted with duplicates. Additionally, different controls were included in the membranes: positive (ESTs corresponding to known T. harzianum genes), negative (library vector, PCR buffer) and charge controls composed of RNAs obtained by in vitro transcription of some plantspecific genes. RNA was isolated as described under 'DNA and RNA hybridizations'. For macroarray hybridization, the probe was prepared by reverse transcription using $12.5 \mu \mathrm{g}$ total RNA, $7 \cdot 5 \mu \mathrm{Ci}$ $(227 \mathrm{kBq})\left[\alpha^{32} \mathrm{P}\right] \mathrm{dCTP}$ and $1 \mu \mathrm{l}$ PowerScript reverse transcriptase (Clontech) per membrane $(9 \times 12 \mathrm{~cm})$, following the manufacturer's indications. Reaction efficiency was quantified by means of a scintillation counter.

Hybridization and image acquisition. Prehybridization and hybridization were performed at $65^{\circ} \mathrm{C}$. Membranes were prehybridized in Church buffer $(0.5 \mathrm{M}$ sodium phosphate buffer, $\mathrm{pH} 7 \cdot 2 ; 10 \mathrm{mM}$ EDTA; $7 \%, \mathrm{w} / \mathrm{v}$, SDS) for $1 \mathrm{~h}$ and then hybridized using $10-15 \mathrm{~m}$ fresh buffer per $9 \times 12 \mathrm{~cm}$ membrane. The radioactive probe was added appropriately diluted to obtain $5 \times 10^{5}$ c.p.m. per ml hybridization buffer. After overnight hybridization, membranes were washed three times with washing buffer $(0.04 \mathrm{M}$ sodium phosphate buffer, $\mathrm{pH} 7 \cdot 2 ; 0 \cdot 1 \%, \mathrm{w} / \mathrm{v}, \mathrm{SDS})$ at $65^{\circ} \mathrm{C}$. Then membranes were wrapped with one layer of transparent film and exposed for $3 \mathrm{~h}$ on a Packard Multipurpose MP intensifying screen and the image was obtained using a Cyclone Storage Phosphor System (Perkin Elmer). Three independent hybridizations were performed using different probes and membranes.

Data analysis. The image of the hybridized membrane was analysed using Phoretix Array v3.1 (Nonlinear Dynamics). Two main procedures were applied to this image: first a background control subtraction of the median spot edge average, and then normalization of dot intensities on the basis of the intensity of some internal controls. Dots with intensity values below the mean intensity of negative controls were discarded for further analysis. Each EST was dotted in duplicate, and each membrane was hybridized three times. Dot and replica mean and standard deviation were calculated for the whole membrane to determine the accuracy of the experiment. Finally, the ratio intensity between two different experiments (test and control conditions) was calculated. An arbitrary threshold of twofold difference in intensity levels was established to identify genes as differentially expressed.

Phosphorylation assay. For analysis of the phosphorylation state of p38 MAPKs, mycelia grown as indicated above were frozen, ground in a mortar and suspended in phosphatases inhibition buffer $(10 \%$, w/v, glycerol, $50 \mathrm{mM}$ Tris/HCl, pH 7.5, $150 \mathrm{mM} \mathrm{NaCl}$,
$5 \mathrm{mM}$ EDTA, $1 \%$ Triton X-100, $0 \cdot 1 \%$ SDS, $50 \mathrm{mM} \mathrm{NaF}, 5 \mathrm{mM}$ sodium pyrophosphate, $50 \mathrm{mM} \beta$-glycerophosphate, $1 \mathrm{mM}$ sodium orthovanadate, $1 \mathrm{mM}$ PMSF, and $25 \mu \mathrm{g} \mathrm{ml}^{-1}$ each of tosylphenylalanine chloromethyl ketone, tosyllysine chloromethyl ketone, pepstatin-A, antipain, leupeptin and aprotinin) (Delgado-Jarana et al., 2005). Samples were homogenized and centrifuged to pellet the cell debris. Protein concentration of the supernatant was determined using the Lowry assay. Fifty micrograms of total protein was separated by SDS- $12 \%$ PAGE and blotted onto Immobilon-P membranes (Millipore), following the manufacturer's instructions. Membranes were blocked using $2 \%$ non-fat skimmed milk for 1 h. p38 MAPK was detected using the PhosphoPlus p38 MAPK antibody kit (Cell Signalling Technology), following the manufacturer's instructions. Coomassie-blue-stained gels were used as loading control.

Fluorescence microscopy. Localization of the nuclear green fluorescent protein (GFP)-tagged Hogl protein was determined by fluorescence microscopy. A chimeric hogl-gfp gene was obtained as follows. A hog1 cassette containing promoter and gene was amplified from genomic DNA by PCR using primers 5'-GGTCGACCTGTGTCCCTTCATTACTTC- $3^{\prime}$ and $5^{\prime}$ TCACTAGTTTGTGTGGGGAATTGCTCC-3', which added Sall and SpeI sites, respectively (underlined). These enzymes were used to clone the fragment into pZEGA1 vector (Zeilinger et al., 2003) previously cut with XhoI and XbaI. The resultant vector pHog1-GFP was used to transform T. harzianum using a PEG-based protocol (Penttila et al., 1987). Of the transformed strains, two showed only one copy of pHog1-GFP vector and were chosen for microscopy analysis. Transformed strains were grown in MM for $24 \mathrm{~h}$. Hyperosmotic shock was achieved by mixing the culture with an equal volume of $2 \mathrm{M}$ sorbitol. Oxidative stress was assayed by adding $10 \mathrm{mM} \mathrm{H}_{2} \mathrm{O}_{2}$. Cultures were grown for $1 \mathrm{~h}$ whereas untreated cultures were maintained as control. Formaldehyde was then added up to a final concentration of $4 \%(\mathrm{w} / \mathrm{v})$ and maintained for $10 \mathrm{~min}$ at room temperature. Cells were then centrifuged, suspended in PBS/formaldehyde (PBS containing $4 \%$, w/v, formaldehyde) and maintained for $1 \mathrm{~h}$ at room temperature. Finally, cells were washed twice with PBS and treated with $1 \mu \mathrm{g} 4^{\prime}, 6-$ diamidino-2-phenylindole (DAPI) $\mathrm{ml}^{-1}$. DAPI and GFP fluorescence were captured by exciting cells with 365 and $450-490 \mathrm{~nm}$ wavelengths, respectively, by using a Olympus BX60F5 microscope with a $40 \times$ objective, a Leica DFC300 Fx camera and an IM50 Leica imaging system.

DNA and RNA hybridizations. Standard molecular techniques were performed as described elsewhere (Sambrook \& Russell, 2001). For nucleic acid isolation, mycelia harvested from different culture conditions were frozen in liquid nitrogen, lyophilized and ground to a fine powder. Genomic DNA extractions were done according to previously described procedures (Raeder \& Broda, 1985). Total RNA extractions were performed with Trizol reagent (Invitrogen), following the manufacturer's indications. For Northern experiments, $10 \mu \mathrm{g}$ total RNA from each sample was separated on $1 \cdot 2 \%$ agaroseformaldehyde gels, blotted onto nylon membranes, and hybridized (Sambrook \& Russell, 2001). Blots were probed with the indicated DNA fragments. Probes were labelled with $\left[\alpha_{-}{ }^{32} \mathrm{P}\right] \mathrm{dCTP}$ by using the Ready-To-Go Oligolabelling kit (Amersham Biosciences). The loading of Northern blots was checked using radish $18 \mathrm{~S}$ rRNA as a probe.

Stress cross-protection experiments. Cells from wild-type, FS12 and SHM1 strains were grown in $40 \mathrm{ml}$ TSB cultures $\left(10^{6}\right.$ conidia $\mathrm{ml}^{-1}$ ) for $9 \mathrm{~h}$. Cultures were treated for $1 \mathrm{~h}$ with the following conditions: untreated control, oxidative stress $\left(0.4 \mathrm{mM} \mathrm{H}_{2} \mathrm{O}_{2}\right)$ and osmotic stress $(0 \cdot 3 \mathrm{M} \mathrm{NaCl})$. Mycelia were collected by centrifugation, washed in pre-warmed TSB medium, and resuspended in $10 \mathrm{ml}$ TSB medium. Aliquots of $2 \mathrm{ml}$ were taken in triplicate and treated for $1 \mathrm{~h}$ as follows: untreated control, $10 \mathrm{mM}, 25 \mathrm{mM}$ and $50 \mathrm{mM}$ 
$\mathrm{H}_{2} \mathrm{O}_{2}$, at $28^{\circ} \mathrm{C}$ and 200 r.p.m. Finally, cells were diluted and plated at $30^{\circ} \mathrm{C}$ for 2 days. Survival was expressed as percentage of viable cells at zero time. The experiment was repeated three times.

\section{RESULTS}

\section{Genomic analysis of the response of $T$. harzianum to osmotic shock}

In order to study the stress response of T. harzianum, we performed an array analysis comparing RNA samples of T. harzianum growing under standard growth conditions (minimal medium, MM) versus hyperosmotic shock (MM containing $1.2 \mathrm{M}$ sorbitol) conditions. We analysed membranes with 2496 unique ESTs arrayed. These sequences were obtained under the EST sequencing project TrichoEST (www.trichoderma.org) (Rey et al., 2004). The probes were obtained using $16 \mathrm{~h}$ germlings that were grown in MM (control) or MM containing $1.2 \mathrm{M}$ sorbitol for $2 \mathrm{~h}$. RNA was extracted, labelled and used to hybridize array membranes. Those ESTs that showed a twofold induction level in the sorbitol sample were considered to be induced by hyperosmotic stress. Around 70 ESTs were identified using this criterion (Table 1). Although a number of entries without identifiable similarity were detected, some genes encoding proteins putatively involved in redox reactions and sugar metabolism, as well as genes involved in defence, development and signal transduction, were induced in highosmolarity medium. The gene that showed the highest induction level was highly homologous to the NRC-2 kinase from $N$. crassa, which seems to repress conidiation (Kothe \& Free, 1998). A gene related to the yeast CKS1 protein was also induced. Interestingly, cks1 null mutants showed high salt sensitivity (Yu \& Reed, 2004). Several oxidoreductases were also induced (cytochrome P450 oxidoreductase, NADP-specific glutatamate dehydrogenase, alternate oxidase, quinone oxidoreductase, glutaryl-CoA dehydrogenase). This high expression of oxidoreductases may counteract the oxidative stress and provide NADPH for detoxification, or be involved in metabolism of oxidized molecules (Causton et al., 2001; Chen et al., 2003; Hohmann, 2002). Genes putatively implicated in acting against unrelated stress factors were also identified, such as one $30 \mathrm{kDa}$ heatshock protein also described in yeasts (Chen et al., 2003; Rep et al., 2000), and one putative ABC transporter. Some of the upregulated genes seem to be related to energy-providing pathways. This phenomenon has also been described in yeasts (Gasch et al., 2000). One putative hexose transporter, one glucoamylase precursor, the glycolytic enzyme fructose1,6-bisphosphatase, genes encoding proteins involved in the TCA cycle (succinyl-CoA synthetase) and respiration (mitochondrial 2-oxodicarboxylate carrier, cytochrome $c$ oxidase), or an ATPase can be identified in this group. The energy requirement is higher under osmotic shock due to the demand of ATP by chaperones to maintain the intracellular $\mathrm{pH}$ and to produce solutes and cell protectants (Causton et al., 2001). Taken together, these results indicate that $T$. harzianum develops a broad response under osmotic stress, covering different metabolic areas.

\section{Characterization of the hog1 gene}

Since the pivotal enzyme in response to osmotic stress in yeasts is the MAPK Hog1 we tried to identify HOG1 gene homologues in T. harzianum. We performed an in silico screening over the described EST database using the TBlastN algorithm (Altschul et al., 1997). Several ESTs which putatively coded for Hog1 MAP kinase were isolated. The cDNA clone was $1.3 \mathrm{kbp}$ long, with $102 \mathrm{bp}$ before an ORF of $1068 \mathrm{bp}$ and a short $3^{\prime}$ end sequence of $216 \mathrm{bp}$ before the polyadenosine tail. A genomic clone of $4.2 \mathrm{kbp}$ was fully sequenced and analysed. No 5'-TATAAA sequence was found, but three $5^{\prime}$-CCAAT sequences were located at $-328 \mathrm{bp},-425 \mathrm{bp}$ and $-622 \mathrm{bp}$ with respect to ATG. No polyadenylation sequence was detected as described by Ballance (1986). The start codon environment (5'TCACAATG) matched the consensus described in T. harzianum: $55^{\prime}$-(T/C)CAA(A/C)ATG (Goldman et al., 1998). When comparing the cDNA and the genomic clone, nine exons were located to complete the ORF deduced from the cDNA sequence.

Translation of this ORF yielded a 356 aa putative protein. This protein was analysed using the InterProScan tool from EMBL-EBI (http://www.ebi.ac.uk/InterProScan/) and several domains were detected. Among them, protein kinase (IPR000719), comprising the ATP-binding domain between amino acids 26 and 50, and serine-threonine protein kinase (IPR002290), covering positions 20-299, produced the highest scores. The deduced protein also showed the TGY domain in position 171, which is involved in phosphorylation in the p38 family of MAP kinases (Widmann et al., 1999). Moreover, a phenylalanine residue (position 315) which can be mutated to serine to obtain hyperactive mutant alleles (Bell et al., 2001) was also identified. We concluded that the EST identified coded for a protein highly similar to the yeast MAPK HOG1 gene. The corresponding gene in T. harzianum was named hogl. The deduced protein (ThHog1) was highly homologous to $\mathrm{p} 38$ proteins cloned in filamentous fungi and yeasts. Lack of similarity is only observed at the carboxyl end, where Hoglp from S. cerevisiae showed a long terminal tail (344-439 residues) which is not present in proteins from filamentous fungi.

\section{The hog1 gene from $T$. harzianum is able to complement the hog1 $\Delta$ mutation in yeast}

To confirm that the hog1 gene from T. harzianum was homologous to S. cerevisiae HOG1, we complemented the hog $1 \Delta$ mutation in baker's yeast. Yeasts transformed with the empty pES86 vector did not grow on YNB plates supplemented with $0.4 \mathrm{M} \mathrm{NaCl}$ (Fig. 1). As expected, yeasts transformed with vector carrying T. harzianum hogl or yeast HOG1 were able to grow in $\mathrm{YNB}+0 \cdot 4 \mathrm{M} \mathrm{NaCl}$, which confirmed that the two genes were homologues. However, when higher amounts of $\mathrm{NaCl}$ were used, yeasts transformed 
with the $T$. harzianum hog1 gene grew profusely when compared with those transformed with yeast HOG1 (Fig. 1). This suggests that differences between the two proteins could reflect distinct functional characteristics.

In yeasts, overexpression of HOG1 produces lethality in PBS2 cells (Hohmann, 2002). Hog1 depends on Pbs2 to be activated since $H O G 1$ overexpression does not enable $p b s 2 \Delta$ cells to grow on high-salt media (Bell et al., 2001). Taking advantage of this phenotype, a hyperactive $H O G 1^{\mathrm{F} 318 \mathrm{~S}}$ allele was identified since it rescued $\Delta p b s 2$ cells on high osmolarity medium (Bell et al., 2001). This allele, however, cannot rescue lethality of hog1s yeasts under high-salt conditions (Bell et al., 2001). We checked whether the F315S mutation in T. harzianum hog1 $\left(\operatorname{hog}_{1}{ }^{\mathrm{F} 15 \mathrm{~S}}\right)$ showed the same phenotype. As expected, hog1s yeasts transformed with pES86$H O G 1^{\mathrm{F} 318 \mathrm{~S}}$ did not grow in $\mathrm{YNB}+0 \cdot 4 \mathrm{M} \mathrm{NaCl}$, whereas strains transformed with pES86- $\operatorname{hog} 1^{\mathrm{F} 315 \mathrm{~S}}$ grew copiously even at higher salt concentrations (Fig. 1). Hence, in contrast to the yeast allele $H O G 1^{\mathrm{F} 318 \mathrm{~S}}$ the T. harzianum $h \circ g 1^{\mathrm{F} 315 \mathrm{~S}}$ allele allowed $h \circ g 1 \Delta$ cells to grow under osmotic shock.

\section{T. harzianum ThHog1 protein is phosphorylated under stress conditions}

Hogl protein deduced from T. harzianum hog1 gene (ThHog1) shows the TGY domain which is phosphorylated in threonine and tyrosine residues in p38 MAPK proteins. To check whether the ThHogl protein was phosphorylated, we used phosphorylation-state-specific antibodies for the p38 MAPK family (anti-phospho-P38), which can recognize specifically the TGY domain when the protein is phosphorylated. We tested metabolic stress (carbon, nitrogen and phosphorus deprivation, as well as chitin as sole carbon source), osmotic stress ( $1.2 \mathrm{M}$ sorbitol), saline/osmotic stress $(1 \mathrm{M} \mathrm{NaCl})$, oxidative stress $\left(10 \mathrm{mM} \mathrm{H}_{2} \mathrm{O}_{2}\right)$, heavy metal stress $\left(40 \mathrm{mM} \mathrm{CuSO}_{4}\right)$ and high-pH stress ( $\mathrm{pH} \mathrm{10).}$ All the conditions led to a high level of phosphorylation (Fig. 2). Only extracts obtained from mycelia grown in MM supplemented with glucose and ammonium showed an almost undetectable signal.

\section{ThHog1 protein is localized in nuclei under osmotic stress}

In S. cerevisiae (Reiser et al., 1999), C. albicans (Smith et al., 2004) and the filamentous fungus Colletotrichum lagenarium (Kojima et al., 2004) Hog1 protein accumulates in the nucleus in response to stress. To study whether this phenomenon also occurs in T. harzianum, we constructed a hog1-gfp fusion expressed from the hogl promoter. Strains transformed with the construct showed a diffuse fluorescence when growing in MM (Fig. 3). However, when cells were grown for $1 \mathrm{~h}$ under hyperosmotic shock ( $1 \mathrm{M}$ sorbitol) fluorescence caused by GFP was localized in nuclei, which could be identified by DAPI staining (Fig. 3). Under oxidative stress (using $10 \mathrm{mM} \mathrm{H}_{2} \mathrm{O}_{2}$ ) ThHog1-GFP was also localized in the nuclei, although at lower levels than when using hyperosmotic shock. Hence, hyperosmotic and oxidative stress that caused phosphorylation also provoked nuclear localization of the ThHog1-GFP fusion, although at lower levels under oxidative stress.

\section{Construction of hyperactive and silenced mutants}

In order to check whether ThHogl protein is involved in the stress response in $T$. harzianum, two strains were constructed: a strain carrying the $h \circ g 1^{\mathrm{F} 315 \mathrm{~S}}$ allele overexpressed, and a knockdown hog1-silenced strain, since gene deletion has not been established in T. harzianum CECT 2413. The latter strain was obtained by the use of a hairpin construct (with inverted repeats separated by an intron) that provokes gene silencing mediated by small RNAs (siRNA) (Fig. 4a).

We have not been able to obtain transformants overexpressing the wild-type hog1 allele. Only a few colonies were isolated in several experiments, but none of them integrated this construct. This may be explained considering the phenotypes of yeast mutants. T. harzianum transformation is performed in medium containing $1.2 \mathrm{M}$ sorbitol to stabilize the protoplasts osmotically; that is, a medium where ThHog1 is highly phosphorylated. In yeast mutants, the overexpression of the wild-type allele is lethal under high salt concentration (Fig. 1).

Transformants carrying the hog $1^{\mathrm{F} 315 \mathrm{~S}}$ allele were isolated and checked by Southern blotting. Some of them had integrated one copy of the construct and were chosen for further analysis; only FS12 is shown here. The selection of silenced mutants was performed by isolating small colonies from transformation plates. A strain (SHM1) that showed one integration event and no disruption of the endogenous hogl gene was chosen for further characterization.

Transformants were checked by Northern blot analysis. As expected, strain FS12 showed higher levels of hog1 mRNA both under basal growth conditions and under hyperosmotic shock (Fig. 4b). Strain SHM1 showed decreased, although detectable, levels of hog1 mRNA. When this was quantified, strain SHM1 showed threefold lower hog1 mRNA than the wild-type, whereas the FS12 strain showed two- to threefold higher levels than the wild-type. The levels of phosphorylated protein confirmed the mRNA analysis (Fig. 4c). Strain FS12 showed higher levels of phosphorylated ThHog1 protein under all conditions tested, although these levels were not constitutive. The same mutation in S. cerevisiae mimics the activated form of Hogl without phosphorylation. Moreover, no signal was observed when strain SHM1 was analysed under basal and hyperosmotic shock conditions.

\section{Phenotypic analysis of strains FS12 and SHM1}

The phenotypes of wild-type, FS12 and SHM1 strains were studied using a drop assay (Fig. 5). The two mutants grew, developed and conidiated like the wild-type. Strain SHM1 showed reduced resistance to hyperosmotic shock $(1 \cdot 2 \mathrm{M}$ sorbitol) and salt stress $(1 \mathrm{M} \mathrm{NaCl})$. Lower effects were 
Table 1. ESTs induced after $2 \mathrm{~h}$ growth in MM containing $1 \cdot 2 \mathrm{M}$ sorbitol

\begin{tabular}{|c|c|c|c|c|c|c|c|c|}
\hline \multirow{2}{*}{$\begin{array}{l}\text { Induction } \\
\text { level }^{\star}\end{array}$} & \multicolumn{3}{|c|}{ EST } & \multicolumn{5}{|c|}{ Similarity detected by BLAST analysis of ESTs $\dagger$} \\
\hline & Sequence code & bp & Acc. no. & Acc. no. & Organism & Putative function & Score $\ddagger$ & $E$-value $\$$ \\
\hline$>100$ & L06T34P029R02710 & 685 & AJ898191 & emb|CAD21180 11 & Neurospora crassa & Serine/threonine protein kinase NRC-2 & 415 & $\mathrm{e}-115$ \\
\hline$>100$ & L06T34P031R02920 & 655 & AJ898372 & gblAAS76670 11 & Trichophyton rubrum & Leucine aminopeptidase 2 & 114 & $2 \mathrm{e}-24$ \\
\hline$>100$ & L91T34P045R04188 & 613 & AJ919183 & emblCAF05963·1l & Neurospora crassa & Related to transcription initiation factor & 115 & $9 e-25$ \\
\hline$>100$ & L06T34P031R02954 & 675 & AJ898399 & gb|AAQ04633·1l & Paracoccidioides brasiliensis & Cell cycle regulator protein Clf1 & 297 & $2 \mathrm{e}-79$ \\
\hline$>100$ & L06T34P029R02707 & 659 & AJ898188 & gb|AAL08510·1l & Ophiostoma piliferum & Subtilase & 291 & $1 e-77$ \\
\hline$>100$ & L06T34P030R02792 & 700 & AJ898267 & emblCAA39364 $\cdot 1 \mid$ & Hypocrea jecorina & Orotate phosphoribosyltransferase & 239 & $5 e-62$ \\
\hline$>100$ & L06T34P030R02794 & 656 & AJ898269 & gb|EAL86518·1। & Aspergillus fumigatus & Chromatin remodelling complex subunit (Arp9) & 110 & $2 e-23$ \\
\hline$>100$ & L03T34P023R02176 & 695 & AJ896946 & $\operatorname{gb|EAL86188\cdot 1।}$ & Aspergillus fumigatus & Monosaccharide transporter & 207 & $3 e-52$ \\
\hline$>100$ & L06T34P029R02713 & 546 & AJ898194 & gb|EAL89460·1l & Aspergillus fumigatus & ATP-dependent RNA helicase, putative & 261 & $7 e-69$ \\
\hline$>100$ & L06T34P031R02902 & 734 & AJ898356 & $\operatorname{gb|EAL89621\cdot 1l}$ & Aspergillus fumigatus & Oxidoreductase, zinc-binding dehydrogenase family & 132 & $8 e-30$ \\
\hline$>100$ & L06T34P029R02703 & 369 & AJ898184 & gb|EAA77489·1l & Gibberella zeae & Hypothetical protein FG07472.1 & 48 & $8 e-005$ \\
\hline$>100$ & L02T34P026R02420 & 487 & AJ894575 & gb|EAL91198·1। & Aspergillus fumigatus & Glucose-repressible gene protein-related protein & 65 & $7 e-010$ \\
\hline$>100$ & L06T34P030R02818 & 664 & AJ898290 & gb|EAA77567·1l & Gibberella zeae & Hypothetical protein FG07334.1 & 186 & $4 e-46$ \\
\hline$>100$ & L06T34P029R02729 & 756 & AJ898208 & gb|AAB58299·1l & Hypocrea virens & Carbamoyl phosphate synthetase, small subunit & 421 & $\mathrm{e}-117$ \\
\hline$>100$ & L02T34P013R01198 & 661 & AJ893972 & gb|EAA78739·1l & Gibberella zeae & Conserved hypothetical protein & 375 & $e-103$ \\
\hline $10-20$ & L06T34P029R02715 & 655 & AJ898196 & gb|EAL85453·1l & Aspergillus fumigatus & $\mathrm{K}^{+} / \mathrm{H}^{+}$antiporter, putative & 94 & $2 \mathrm{e}-18$ \\
\hline $10-20$ & L03T34P016R01470 & 730 & AJ896746 & No hits found & & & & \\
\hline $10-20$ & L02T34P054R05008 & 735 & AJ894944 & emb|CAI67598 $\cdot 1 \mid$ & Hypocrea lixii & Glucoamylase & 411 & $e-114$ \\
\hline $10-20$ & L02T34P013R01182 & 299 & AJ893956 & dbj|BAA01859·1l & Saccharomyces cerevisiae & Cks1 protein & 82 & $5 e-15$ \\
\hline $10-20$ & L05T34P051R04715 & 633 & AJ897844 & gblEAL93520 $\cdot 11$ & Aspergillus fumigatus & Cytochrome $c$ oxidase assembly protein Cox11 & 143 & $3 e-33$ \\
\hline $10-20$ & L05T34P051R04776 & 695 & AJ897903 & emblCAE76503 11 & Neurospora crassa & Probable ribosomal protein L35 & 197 & $2 e-49$ \\
\hline $5-10$ & L05T34P051R04763 & 703 & AJ897891 & gb|EAL90014·1l & Aspergillus fumigatus & Cytosolic large ribosomal subunit L11, putative & 294 & $1 e-78$ \\
\hline $5-10$ & L02T34P013R01227 & 681 & AJ893999 & emb|CAB99174 $\cdot 11$ & Neurospora crassa & Related to GTP-binding protein Rab2 & 275 & $1 e-72$ \\
\hline $5-10$ & L02T34P054R05051 & 675 & AJ894980 & gb|EAL88455·1l & Aspergillus fumigatus & Autophagic death protein (Idi-7), putative & 232 & $6 e-60$ \\
\hline $5-10$ & L03T34P075R07048 & 599 & AJ897783 & No hits found & & & & \\
\hline $5-10$ & L08T34P062R05757 & 699 & AJ899490 & gb|EAL88981·1l & Aspergillus fumigatus & $\mathrm{ABC}$ transporter, putative & 206 & $6 e-52$ \\
\hline $5-10$ & L06T34P031R02926 & 712 & AJ898378 & gb|EAA69900 $\cdot 1 \mid$ & Gibberella zeae & Hypothetical protein FG02621.1 & 143 & $5 e-33$ \\
\hline $5-10$ & L10T34P073R06887 & 551 & AJ900032 & gb|EAL89736 $\cdot 1 \mid$ & Aspergillus fumigatus & CSL family zinc-finger-containing protein & 107 & $1 e-22$ \\
\hline $5-10$ & L02T34P020R01850 & 693 & AJ894410 & emb|CAE85545•1l & Neurospora crassa & Related to translation initiation factor eI & 252 & $6 e-66$ \\
\hline $5-10$ & L06T34P032R03066 & 574 & AJ898485 & gblEAA76320·1l & Gibberella zeae & RS7_NEUCR 40S ribosomal protein S7 & 256 & $3 e-67$ \\
\hline $5-10$ & L05T34P051R04760 & 690 & AJ897888 & dbj|BAB85760 11 & Fusarium oxysporum & Putative mitochondrial carrier protein & 364 & $1 e-99$ \\
\hline $5-10$ & L05T34P051R04747 & 703 & AJ897875 & gb|AAX07669·1l & Magnaporthe grisea & Succinyl-CoA ligase beta-chain-like protein & 358 & $8 e-98$ \\
\hline $2-5$ & L02T34P055R05095 & 599 & AJ895019 & gb|EAL89660 $\cdot 1 \mid$ & Aspergillus fumigatus & Fructose-1,6-bisphosphatase & 143 & $3 e-33$ \\
\hline $2-5$ & L10T34P072R06754 & 692 & AJ899902 & $\operatorname{gb|EAL92207\cdot 1।}$ & Aspergillus fumigatus & Cation-transporting ATPase, putative & 133 & $4 e-30$ \\
\hline $2-5$ & L10T34P072R06753 & 628 & AJ899901 & reflNP_967878.1। & Bdellovibrio bacteriovorus & ThiJ/PfpI family protein & 96 & $1 e-18$ \\
\hline $2-5$ & L02T34P004R00295 & 464 & AJ893779 & emb|CAD21258 $\cdot 1 \mid$ & Neurospora crassa & Related to Glc8 protein & 112 & $4 e-24$ \\
\hline $2-5$ & L05T34P051R04775 & 611 & AJ897902 & gb|EAL91198·1l & Aspergillus fumigatus & Glucose-repressible gene protein-related protein & 105 & $7 e-22$ \\
\hline $2-5$ & L02T34P013R01183 & 297 & AJ893957 & gb|EAL92477·1। & Aspergillus fumigatus & SNI2 protein & 84 & $1 e-15$ \\
\hline $2-5$ & L05T34P052R04820 & 633 & AJ897944 & gb|EAA76043 $\cdot 11$ & Gibberella zeae & Hypothetical protein FG07070.1 & 211 & $2 e-53$ \\
\hline
\end{tabular}


Table 1. cont.

\begin{tabular}{|c|c|c|c|c|c|c|c|c|}
\hline \multirow{2}{*}{$\begin{array}{l}\text { Induction } \\
\text { level }^{\star}\end{array}$} & \multicolumn{3}{|c|}{ EST } & \multicolumn{5}{|c|}{ Similarity detected by BLAST analysis of ESTs $\dagger$} \\
\hline & Sequence code & bp & Acc. no. & Acc. no. & Organism & Putative function & Score $\ddagger$ & $E$-value $\S$ \\
\hline $2-5$ & L03T34P022R02080 & 360 & AJ896869 & $\mathrm{emb}|\mathrm{CAC} 28672 \cdot 1|$ & Neurospora crassa & Glucose-repressible protein Grg-1 & 85 & $8 e-16$ \\
\hline $2-5$ & L91T34P045R04199 & 650 & AJ919191 & No hits found & & & & \\
\hline $2-5$ & L06T34P032R03046 & 423 & AJ898470 & gb|EAA68083·1l & Gibberella zeae & RL44_PICJA 60S ribosomal protein L44 (L41) & 221 & $7 e-57$ \\
\hline $2-5$ & L06T34P030R02847 & 601 & AJ898315 & gb|EAA72805 11 & Gibberella zeae & Hypothetical protein FG04424.1 & 213 & $4 e-54$ \\
\hline $2-5$ & L03T34P014R01335 & 467 & AJ896711 & gb|EAA76695 11 & Gibberella zeae & Hypothetical protein FG09376.1 & 70 & $3 e-11$ \\
\hline $2-5$ & L91T34P046R04274 & 677 & AJ919246 & emb|CAE85513·1l & & Related to DNA mismatch repair protein PMS1 & 183 & $3 e-45$ \\
\hline $2-5$ & L10T34P076R07157 & 667 & AJ900107 & gb|EAL93821 11 & Aspergillus fumigatus & Small oligopeptide transporter, OPT family & 155 & $1 e-36$ \\
\hline $2-5$ & L10T34P076R07101 & 667 & AJ900056 & emb|CAC28847·2l & Neurospora crassa & Related to HFB30 & 307 & $2 e-82$ \\
\hline $2-5$ & L02T34P020R01920 & 679 & AJ894457 & No hits found & & & & \\
\hline $2-5$ & L10T34P077R07256 & 608 & AJ900194 & emb|CAD70936•1l & Neurospora crassa & Related to cleft lip and palate transmembrane & 186 & $3 e-46$ \\
\hline $2-5$ & L06T34P029R02700 & 536 & AJ898182 & gb|EAL91000 $\cdot 11$ & Aspergillus fumigatus & Fatty acid elongase (Gig30), putative & 84 & $3 e-15$ \\
\hline $2-5$ & L10T34P072R06724 & 704 & AJ899872 & gb|EAL90295 $\cdot 11$ & Aspergillus fumigatus & Mitochondrial 2-oxodicarboxylate carrier protein & 299 & $4 e-80$ \\
\hline $2-5$ & L03T34P014R01254 & 665 & AJ896635 & gb|EAL86695 11 & Aspergillus fumigatus & Ser/Thr protein phosphatase family & 227 & $2 \mathrm{e}-58$ \\
\hline $2-5$ & L06T34P031R02959 & 691 & AJ898404 & gb|EAA78762 11 & Gibberella zeae & Hypothetical protein FG11590.1 & 266 & $3 e-70$ \\
\hline $2-5$ & L05T34P051R04764 & 681 & AJ897892 & gb|EAL85583·1l & Aspergillus fumigatus & Elongation factor 1 -gamma 2 & 233 & $3 e-60$ \\
\hline $2-5$ & L02T34P003R00211 & 685 & AJ893718 & $\operatorname{gblEAA70102\cdot 1l}$ & Gibberella zeae & Hypothetical protein FG10259.1 & 90 & $6 e-17$ \\
\hline $2-5$ & L03T34P016R01468 & 673 & AJ896744 & No hits found & & & & \\
\hline $2-5$ & L10T34P076R07132 & 515 & AJ900085 & No hits found & & & & \\
\hline $2-5$ & L02T34P001R00060 & 407 & AJ893596 & gb|EAL92964·1l & Aspergillus fumigatus & Glutaryl-CoA dehydrogenase & 181 & $8 e-45$ \\
\hline $2-5$ & L91T34P046R04287 & 666 & AJ919256 & gb|EAA73743 11 & Gibberella zeae & Hypothetical protein FG06252.1 & 153 & $5 e-36$ \\
\hline $2-5$ & L03T34P059R05469 & 554 & AJ897207 & $\operatorname{gblEAA74083\cdot 11}$ & Gibberella zeae & Hypothetical protein FG05206.1 & 48 & $2 \mathrm{e}-04$ \\
\hline $2-5$ & L03T34P023R02114 & 666 & AJ896900 & gb|AAD16095·1l & Aspergillus oryzae & Phosphatidylglycerol/phosphatidylinositol transfer protein & 149 & $5 e-35$ \\
\hline $2-5$ & L02T34P050R04607 & 681 & AJ894750 & gb|EAA48690 11 & Gibberella zeae & Hypothetical protein MG00348.4 & 51 & $3 e-05$ \\
\hline $2-5$ & L08T34P063R05842 & 612 & AJ899574 & No hits found & & & & \\
\hline $2-5$ & L02T34P004R00319 & 697 & AJ893796 & emb|CAE09055•1l & Gibberella zeae & Cytochrome P450 oxidoreductase & 327 & $2 e-88$ \\
\hline $2-5$ & L02T34P054R05069 & 699 & AJ894995 & gblEAA74999·1l & Gibberella zeae & Hypothetical protein FG10742.1 & 268 & $1 e-70$ \\
\hline $2-5$ & L03T34P060R05584 & 693 & AJ897313 & emb|CAC27396•1l & Podospora anserina & Alternative oxidase & 323 & $3 e-87$ \\
\hline $2-5$ & L91T34P045R04191 & 671 & AJ919185 & gb|AAO32939·1l & Neurospora crassa & TIM50 & 345 & $8 e-94$ \\
\hline $2-5$ & L02T34P057R05358 & 710 & AJ895274 & gb|EAL88570 11 & Aspergillus fumigatus & Actin-binding protein, putative & 333 & $2 e-90$ \\
\hline $2-5$ & L03T34P022R02092 & 669 & AJ896880 & gblEAA77790 11 & Gibberella zeae & CT1B_Fusso cutinase transcription factor $1 \mathrm{~B}$ & 341 & $1 e-92$ \\
\hline $2-5$ & L10T34P072R06790 & 635 & AJ899937 & gb|EAA77138 $\cdot 11$ & Gibberella zeae & Hypothetical protein FG09581.1 & 230 & $2 e-59$ \\
\hline $2-5$ & L10T34P076R07178 & 578 & AJ900122 & gb|AAX55622·1l & Hypocrea lixii & Small heat-shock protein & 141 & $1 e-32$ \\
\hline $2-5$ & L03T34P016R01467 & 566 & AJ896743 & gb|AAB28355·1l & Neurospora crassa & $\mathrm{NAD}^{+}$-specific glutamate dehydrogenase; NAD & 180 & $2 \mathrm{e}-44$ \\
\hline $2-5$ & L03T34P022R02091 & 352 & AJ896879 & $\operatorname{gblEAA} 47045 \cdot 11$ & Magnaporthe grisea & Hypothetical protein MG10856.4 & 75 & $6 e-013$ \\
\hline
\end{tabular}

*The induction level is obtained by the ratio of the expression after $2 \mathrm{~h} 1.2 \mathrm{M}$ sorbitol containing culture vs culture without sorbitol.

$\dagger$ †LAST: Basic Local Alignment Search Tool.

$\vec{\sigma} \quad$ GGiven in 'bits'. The bit score is defined as: $S^{\prime}$ (bits) $=[\lambda \times S$ (raw) $-\ln K] / \ln 2$, where $\lambda$ and $K$ are Karlin-Altschul parameters.

$\underset{\omega}{\infty}$ SExpected value. Estimates the statistical significance of a match, specifying the number of matches that are expected in a search of a database of the given size by chance. 

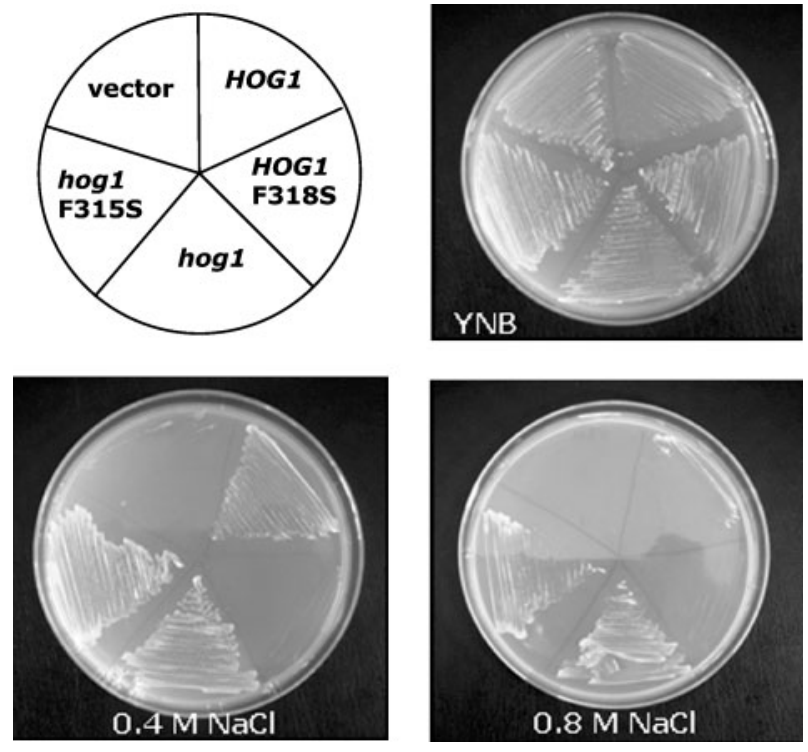

Fig. 1. Complementation analysis of the hog1 gene in budding yeast. Yeasts were transformed with: empty vector pES86 (vector); pES86: HOG1 vector, carrying the HOG1 gene from S. cerevisiae (HOG1); pES86:HOG $1^{\mathrm{F} 318 \mathrm{~S}}$ vector, carrying the $H O G 1^{\mathrm{F} 318 \mathrm{~S}}$ allele from $S$. cerevisiae (HOG1 F318S); pES86: hog 1 vector, carrying the hog 1 gene from $T$. harzianum (hog1); and pES86: $\operatorname{hog} 1^{\mathrm{F} 315 \mathrm{~S}}$ vector, carrying the $\operatorname{hog} 1^{\mathrm{F} 315 \mathrm{~S}}$ allele from $T$. harzianum (hog1 F315S). Where indicated, YNB plates were supplemented with $0.4 \mathrm{M}$ or $0.8 \mathrm{M} \mathrm{NaCl}$.

observed under heavy metal stress $\left(40 \mathrm{mM} \mathrm{CuSO}_{4}\right)$ and oxidative stress conditions $\left(10 \mathrm{mM} \mathrm{H}_{2} \mathrm{O}_{2}\right.$ ). No effect was detected when this strain was stressed by high temperature $\left(37^{\circ} \mathrm{C}\right)$ (Fig. 5a), the cell wall disturbing agent Congo red or $50 \mu \mathrm{M}$ concentration of the oxidative stress agent paraquat (data not shown). No clear phenotypes were observed with strain FS12, which can be explained by the fact that activation of endogenous ThHog1 protein is sufficient to counteract stress conditions.

To test the influence of the $\mathrm{Ca}^{2+}$-calmodulin-activated pathway upon osmotic challenge, the stress sensitivity of the mutants was analysed using the potent inhibitor of the calcium-calmodulin-activated protein phosphatase calcineurin, cyclosporin A (CsA) (Dumont, 2000). In yeast, the calcineurin inhibitor FK506 increases osmotic sensitivity by inducing amino acid starvation (Rodriguez-Hernandez et al., 2003). However, when using CsA in T. harzianum, no changes in stress resistance were observed (Fig. 5b). Strain FS12 showed a slightly enhanced resistance to MM + CsA when compared to the wild-type in MM, whereas strain SHM1 grew poorly, suggesting connections between the two signalling pathways.

T. harzianum is able to develop parasitic interactions with fungal hosts as a part of its antagonistic abilities. During all these biotic interactions, T. harzianum has to confront different metabolites, cell wall polymers and intracellular

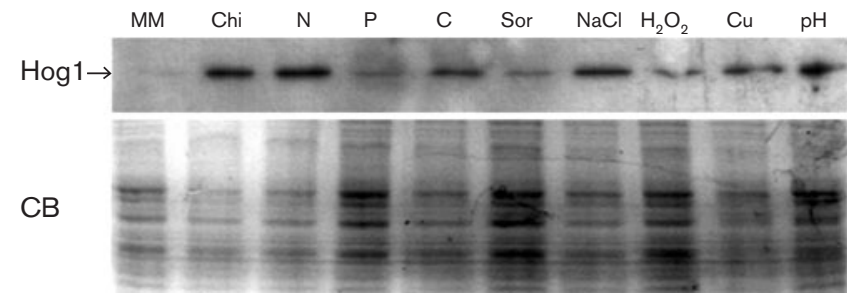

Fig. 2. Western blot analysis of phosphorylation state. Protein extracts obtained as described in Methods were separated by SDS-12\% PAGE and blotted onto membranes. Antibodies specific for the phosphorylation state of p38-related MAPK were used. An identical gel was stained with Coomassie blue (CB) as loading control. Conidia were grown for $16 \mathrm{~h}$ in TSB medium. Germlings were filtered and inoculated into different fresh minimal media: MM supplemented with glucose and ammonium sulphate (MM); $\mathrm{MM}$ supplemented with $1 \%(\mathrm{w} / \mathrm{v})$ colloidal chitin instead of glucose as carbon source (Chi); with $0.002 \%$ ammonium sulphate $(\mathrm{N})$; without phosphate source $(\mathrm{P})$; with $0.1 \%$ glucose $(\mathrm{C})$; or $\mathrm{MM}$ supplemented with $1.2 \mathrm{M}$ sorbitol (Sor); $1 \mathrm{M} \mathrm{NaCl}(\mathrm{NaCl}) ; 10 \mathrm{mM} \mathrm{H}_{2} \mathrm{O}_{2}\left(\mathrm{H}_{2} \mathrm{O}_{2}\right) ; 40 \mathrm{mM}$ $\mathrm{CuSO}_{4}(\mathrm{Cu})$ or at $\mathrm{pH} 10(\mathrm{pH})$. Incubation was continued for $1 \mathrm{~h}$ before protein extraction.

environments. To study whether the ThHog1 protein is involved in these processes, the wild-type, FS12 and SHM1 strains were assayed for their ability to antagonize plantpathogenic fungi such as Botrytis cinerea, Rhizoctonia solani, C. acutatum, $P$. betae and Sclerotium sclerotiorum. No differences were observed except with $C$. acutatum and P. betae (Fig. 6). In both situations, T. harzianum wild-type strain grew over the other fungus, and sporulated profusely. However, both strains FS12 and SHM1 did not overgrow, and consequently did not conidiate on the surface of the phytopathogenic fungi. Moreover, a slight clearing hallus was observed in the interaction zone, suggesting a role of ThHog1 in those fungus-fungus interactions.

\section{Cross-resistance mediated by Hog1}

The existence of a general stress response in S. cerevisiae, Schiz. pombe and C. albicans has been proposed to explain the cross-resistance phenomenon (Chen et al., 2003; Lewis et al., 1995; Smith et al., 2004). The exposure to a stress agent (e.g. oxidative) at low concentrations (non-lethal) can protect against further stronger related and non-related stress conditions (e.g. salt stress). In order to study whether this mechanism is also present in T. harzianum we studied the protective effect of $\mathrm{H}_{2} \mathrm{O}_{2}$ and $\mathrm{NaCl}$ against strong oxidative stress. Nine-hour germlings were treated for $1 \mathrm{~h}$ with $0.3 \mathrm{mM} \mathrm{H}_{2} \mathrm{O}_{2}$ or $0.4 \mathrm{mM} \mathrm{NaCl}$. The germlings were then washed and grown for $1 \mathrm{~h}$ in media with increasing lethal concentrations of $\mathrm{H}_{2} \mathrm{O}_{2}$. Finally, the germlings were diluted and plated. The untreated wild-type cells showed an extreme sensitivity to $\mathrm{H}_{2} \mathrm{O}_{2}$, whereas germlings pre-treated with $\mathrm{NaCl}$ showed higher resistance, which was increased in germlings pre-treated with $\mathrm{H}_{2} \mathrm{O}_{2}$ (Fig. 7a). The same 

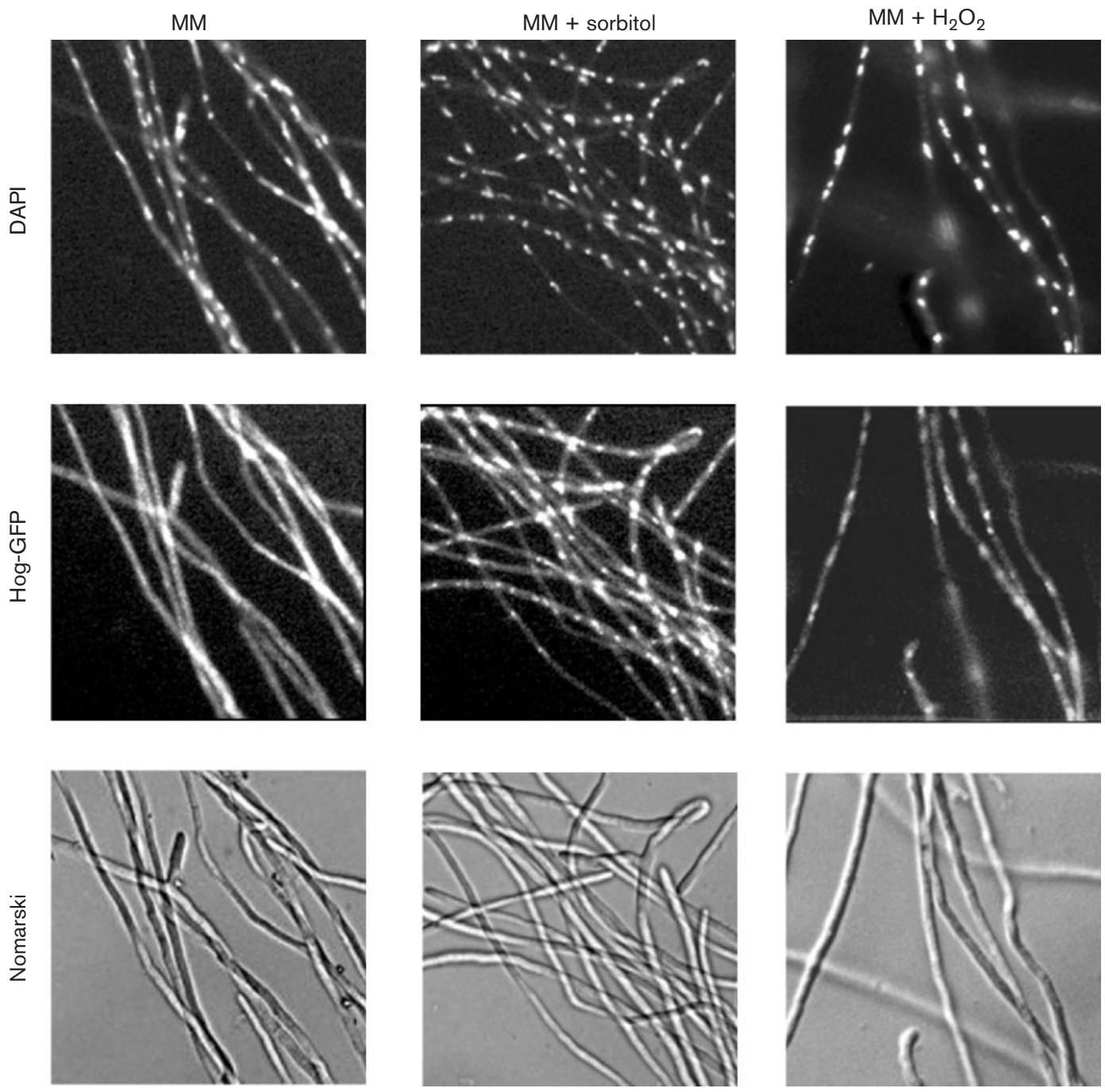

Fig. 3. Localization of the Hog1-GFP fusion protein. Twenty-four-hour germlings of the $T$. harzianum strain carrying the Hog1-GFP fusion were grown for $1 \mathrm{~h}$ under different conditions: MM (minimal medium with glucose and ammonium sulphate, as control); $\mathrm{MM}+1 \mathrm{M}$ sorbitol; $\mathrm{MM}+10 \mathrm{mM} \mathrm{H}_{2} \mathrm{O}_{2}$. Cells were then fixed with formaldehyde and the nuclei stained with DAPI (see Methods). Fluorescence of DAPI and the GFP fusion (HOG-GFP) was examined. The Nomarski technique was used as a control.

phenomenon was also observed in strain SHM1 (Fig. 7b). The resistance in non pre-treated FS12 cells was much higher than that observed in the wild-type (Fig. 7c), and the same was observed for the salt pre-treated cells. Hence, a stress cross-protection partially dependent on ThHog1 is also present in T. harzianum, which suggests the existence of a general stress response in this fungus. Taken together, these findings also raise the possibility that the crossresistance mediated by oxidative stress would not be fully dependent upon ThHog1 in T. harzianum.

\section{DISCUSSION}

In this paper we describe the stress response of $T$. harzianum. We have characterized the hogl gene, which codes for a protein highly similar to the yeast MAPK Hog1. Some different characteristics related to Hog1 MAPK function are observed between budding yeast and T. harzianum. Overexpression of T. harzianum hog1 and $h \circ g 1^{\mathrm{F} 315 \mathrm{~S}}$ alleles in $\Delta$ hogl yeasts resulted in enhanced osmotic resistance, contrasting with yeast $H O G 1$ and $H O G 1^{\mathrm{F} 18 \mathrm{~S}}$ gene overexpression, which caused lethality under osmotic shock. The presence (in yeast) or absence (in T. harzianum) of the long carboxyl-terminal domain as well as other subtle divergences detected may be responsible for the functional differences observed.

ThHogl seems to be mainly involved in the hyperosmotic shock response since only minor effects are observed in hog1 silenced mutants under oxidative or heavy metal stress. This situation is similar to that of baker's yeast. S. cerevisiae hog1s 
(a) $\quad$ PLMRS3 : $\operatorname{hog} 1 \mathrm{~F} 315 \mathrm{~S}$
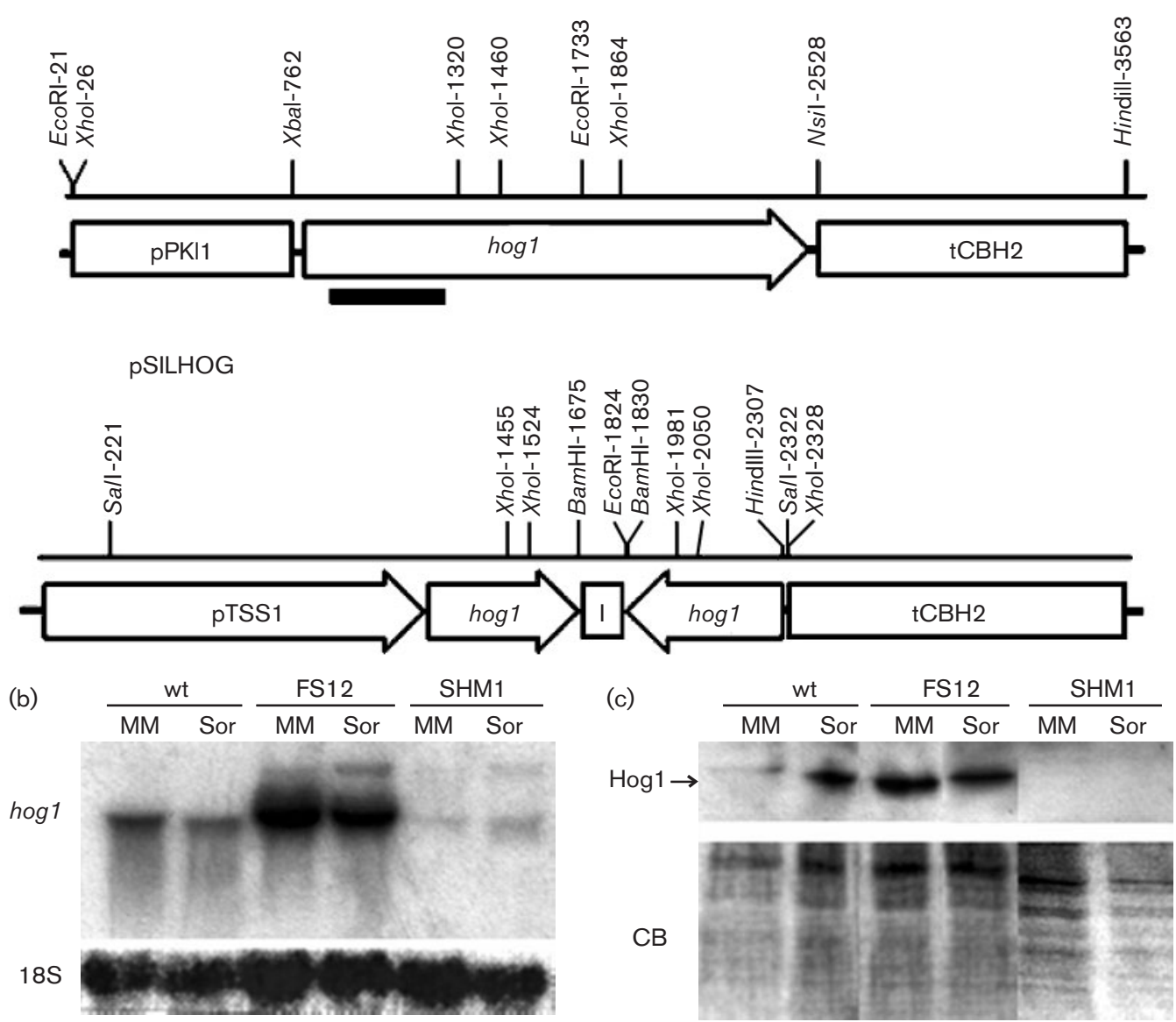

Fig. 4. Mutant strains of $T$. harzianum. (a) Constructs used to transform T. harzianum CECT 2413: pLMRS3: hog $1^{\mathrm{F} 315 \mathrm{~S}}$, carrying the pyruvate kinase promoter from $T$. reesei controlling the expression of $h \circ g 1^{\mathrm{F} 315 \mathrm{~S}}$ allele; pSILHOG, containing inverted repeats of the $5^{\prime}$ end of the coding sequence of hog 1 (black bar in pLMRS3 : hog 1 construct) separated by an intron. The strong tss 1 promoter was used to express the hairpin construct to provoke hog1 silencing. (b) Northern blot analysis. Wild-type (wt), the strain carrying pLMRS3: $\operatorname{hog} 1^{\mathrm{F} 315 \mathrm{~S}}$ (FS12) and the silenced strain (SHM1) were grown for $16 \mathrm{~h}$ in TSB, then washed and inoculated in minimal medium (MM), and MM supplemented with $1.2 \mathrm{M}$ sorbitol (Sor), and grown for $1 \mathrm{~h}$. RNA was blotted onto nylon membranes and hybridized with hog1 probe and with 18S rRNA as loading control. (c) Western blot analysis of intracellular proteins extracted as indicated in (b). Proteins were blotted and membranes analysed with specific antibodies against the phosphorylated TGY domain of p38 MAPK. The arrow indicates the signal revealed with anti-p38 antibodies. Coomassie blue (CB) staining was used as loading control.

mutants are affected in the hyperosmotic shock response (Brewster et al., 1993; Gasch et al., 2000; Hohmann, 2002), and effects related to oxidative stress resistance have only recently been described (Bilsland et al., 2004). This indicates the existence of alternative and complementary mechanisms to counteract oxidative stress (Lev et al., 2005). On the other hand, in Schiz. pombe, deletion of $s t y 1 / s p c 1$ inactivates the response against different stresses (Degols \& Russell, 1997; Degols et al., 1996; Shiozaki \& Russell, 1997).

Although the silencing of hog1 provoked only minor effects over oxidative stress resistance, a role for ThHog1 in this cellular process cannot be discarded. Preliminary evidence of the existence of other factors that may be interacting with
ThHog1 in T. harzianum to control oxidative stress is provided by cross resistance experiments. The wild-type, silenced mutant SHM1 and strain FS12 showed a similar $\mathrm{H}_{2} \mathrm{O}_{2}$-induced cross resistance. This suggested a different system to ThHog1 to respond to oxidative damage. Oxidative stress provoked only a barely detectable effect on the viability of strain FS12 when compared to wild-type. This phenotype could be explained if those factor(s) involved in oxidative stress resistance were partially dependent on ThHog1. Candidates are Rck1 and Rck2 kinases or similar proteins (Bilsland et al., 2004), which could be highly phosphorylated by $\mathrm{ThHog} 1^{\mathrm{F} 315 \mathrm{~S}}$ protein (in strain FS12), but also activated by another kinase(s) when ThHog1 is absent (in strain SHM). 


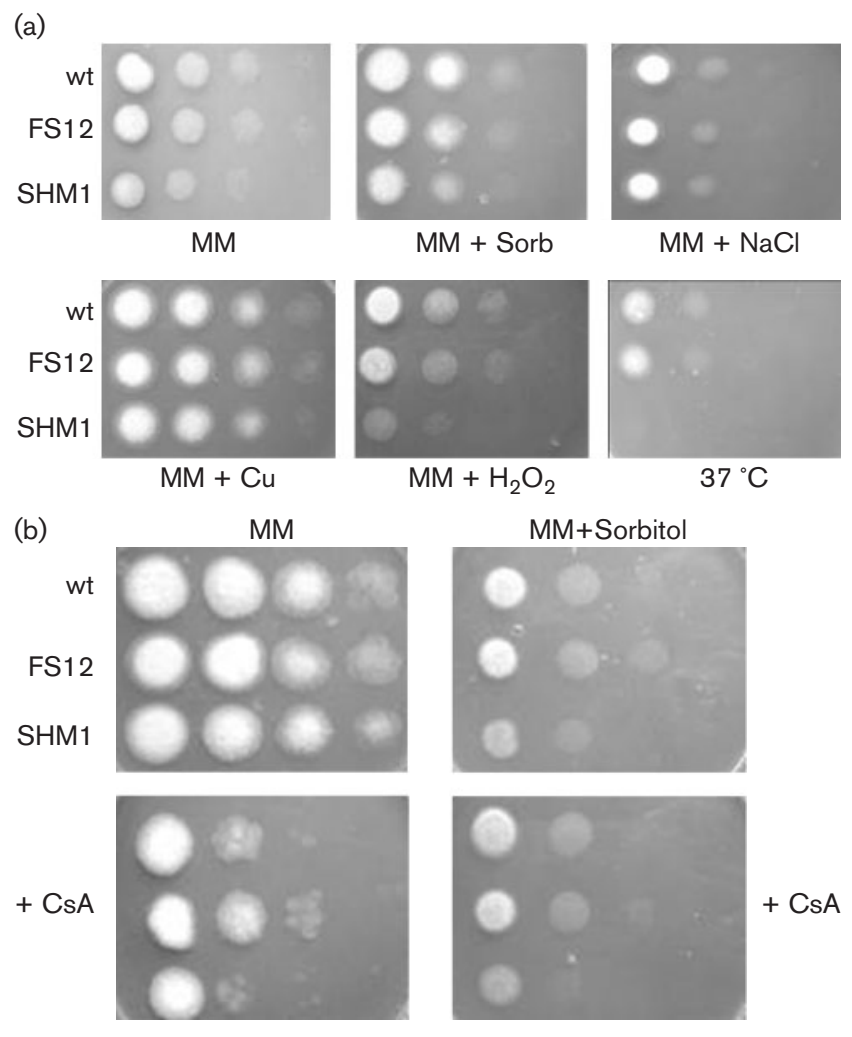

Fig. 5. Phenotypic analysis of hog 1 mutant strains. (a) Three microlitres of conidial suspensions $\left(2 \times 10^{7}\right.$ conidia $\left.\mathrm{ml}^{-1}\right)$ of wild-type (wt), FS12 and SHM1 strains and tenfold serial dilutions were dropped onto plates with: minimal medium (MM); MM plus 1.2 $\mathrm{M}$ sorbitol (MM+Sorb); $\mathrm{MM}$ plus $1 \mathrm{M} \mathrm{NaCl}$

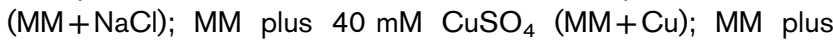
$10 \mathrm{mM} \mathrm{H} \mathrm{O}_{2}\left(\mathrm{MM}+\mathrm{H}_{2} \mathrm{O}_{2}\right)$ and $\mathrm{MM}$ incubated at $37^{\circ} \mathrm{C}$. (b) CsA plates contained $10 \mu \mathrm{g}$ cyclosporin $\mathrm{A} \mathrm{ml}^{-1}$.

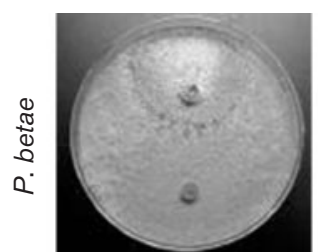

wt

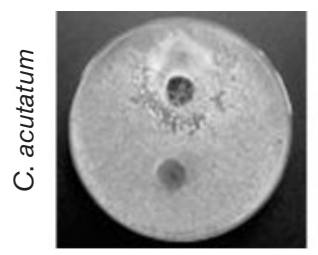

wt

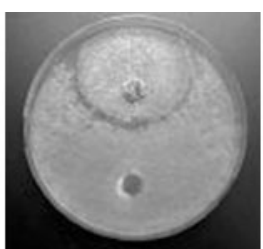

FS12

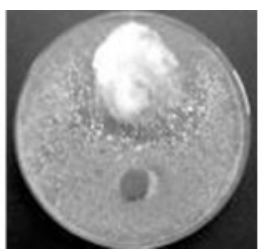

FS12

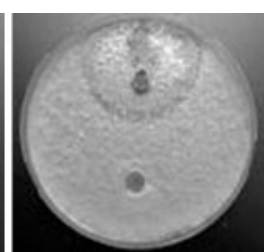

SHM1

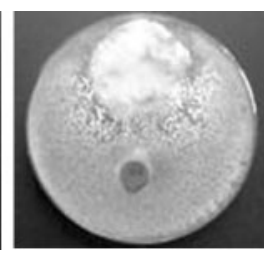

SHM1
Fig. 6. Mycoparasitic analysis of hog 1 mutant strains. Seven-dayold mycelium plugs were inoculated onto PDA plates from wildtype (wt), FS12 and SHM1 strains. The phytopathogenic fungi used were Phoma betae and Colletotrichum acutatum. Plates were incubated for 1 week at $25^{\circ} \mathrm{C}$ and then photographed.
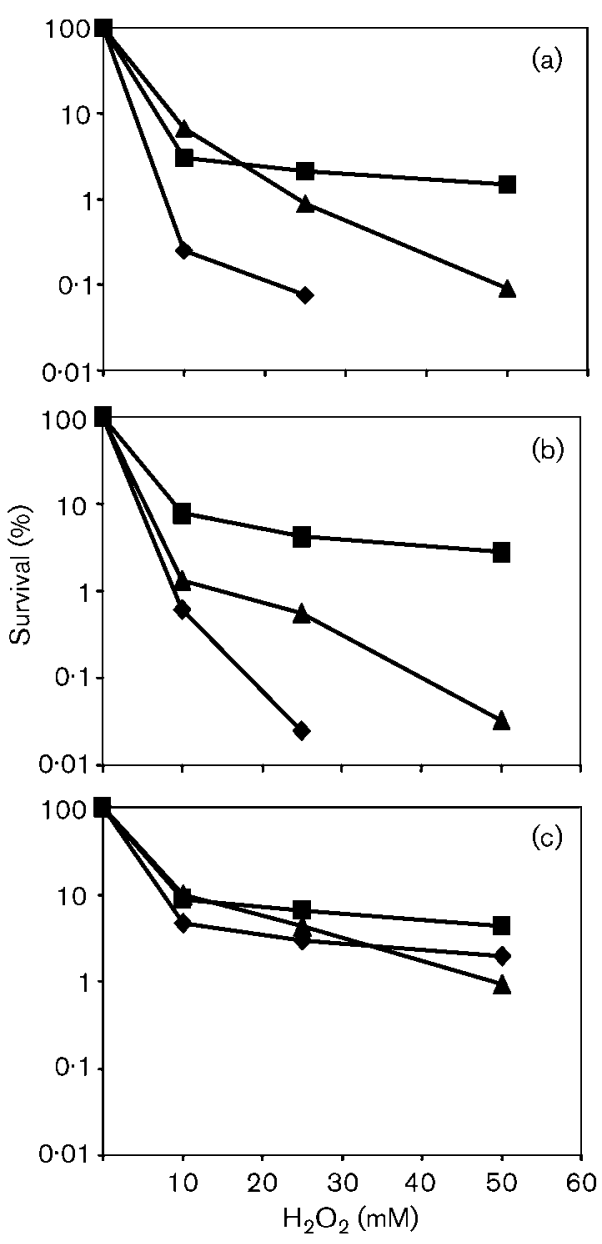

Fig. 7. Stress cross-protection in T. harzianum. Nine-hour germlings of wild-type (a), SHM1 (b) and FS12 (c) strains were either unstressed (control, $\diamond$ ), or pretreated for $1 \mathrm{~h}$ with osmotic stress $(0.3 \mathrm{M} \mathrm{NaCl}, \boldsymbol{\Delta})$ or low-dose oxidative stress $\left(0.4 \mathrm{mM} \mathrm{H}_{2} \mathrm{O}_{2}, \boldsymbol{\square}\right)$. Cells were then washed and treated with increasing $\mathrm{H}_{2} \mathrm{O}_{2}$ concentrations $(10,25$ and $50 \mathrm{mM})$ for $1 \mathrm{~h}$, diluted and plated onto PDA medium to determine remaining viability. The experiment was repeated three times with similar results.

We also found preliminary evidence of cross-talk between the calcineurin and HOG pathways. CsA, a potent inhibitor of the protein phosphatase calcineurin, did not increase sensitivity to osmotic stress as has been described in yeast for another calcineurin inhibitor, FK506 (RodriguezHernandez et al., 2003). Moreover, strains carrying the $h \circ g 1^{\mathrm{F} 315 \mathrm{~S}}$ allele were less affected by toxicity of CsA. Toxicity could not be relieved by an excess of tryptophan (data not shown). Therefore, this may be a different phenomenon from that described in yeasts and mammals using FK506 (Rodriguez-Hernandez et al., 2003; Sanchez-Perez et al., 2004). This result raises the possibility of the HOG and $\mathrm{Ca}^{2+}$ pathways acting over common processes (Maeta et al., 2005), since only overexpression of $h \circ g 1^{\mathrm{F} 315 \mathrm{~S}}$ can restore, at least in 
part, the normal growth inhibited by CsA. Moreover, the silenced strain was highly affected by CsA.

Hog1 kinases have been mainly described as being involved in stress control, but there is no evidence supporting other roles. In M. grisea, mutation in osm1 (homologue to hog1) did not impair pathogenic ability (Dixon et al., 1999). On the contrary, hog1 null mutation caused a drastic fall in development in B. cinerea pathogenesis (Professor Paul Tudzinsky, personal communication). The role of other MAP kinases in the antagonistic activity of Trichoderma species over fungi has been studied. The same MAPK has been cloned and characterized in two different strains of Trichoderma virens (Mendoza-Mendoza et al., 2003; Mukherjee et al., 2003). Interestingly, the loss-of-function mutant obtained covered three different phenotypes: unaffected interaction with $R$. solani, reduced parasitism over Sclerotium rolfsii and enhanced antagonism against a different strain of $R$. solani. This strong variability may be due to the wide variety of mechanisms used by Trichoderma to antagonize other fungi (Mendoza-Mendoza et al., 2003; Mukherjee et al., 2003). This was also observed in this study since changes in mycoparasitic ability were detected with $P$. betae and C. acutatum but not with B. cinerea, R. solani or $S$. sclerotiorum. ThHogl protein could be involved in neutralizing stress agents produced by these parasitized fungi, such as reactive oxygen species. The result obtained with the silenced strain points to the requirement of intact ThHog1 for some parasitic interactions. The phenotype observed for strain FS12 can be explained if the hog ${ }^{\mathrm{F} 315 \mathrm{~S}}$ allele disturbs other signalling pathways required for mycoparasitism. Calcineurin has been claimed as a key regulator of pathogenicity (Fox et al., 2001; Kraus \& Heitman, 2003; Lengeler et al., 2000). Moreover, the calcineurin and HOG pathways show antagonistic regulation over some developmental processes in yeasts (Shitamukai et al., 2004). If active calcineurin is involved in fungus-fungus interactions, we cannot rule out the possibility of impaired antagonistic abilities of strains carrying a hyperactive allele of the hog1 gene.

\section{ACKNOWLEDGEMENTS}

The work was supported by the UE FP5 programme (UE-QLKT-200202032, TrichoEST), Fundación Ramón Areces and the Junta de Andalucía (PAI CVI-107). The authors would like to thank Cristina Rigueiro and Carmen Sánchez for their helpful assistance.

\section{REFERENCES}

Alonso-Monge, R., Navarro-Garcia, F., Roman, E., Negredo, A. I., Eisman, B., Nombela, C. \& Pla, J. (2003). The Hogl mitogenactivated protein kinase is essential in the oxidative stress response and chlamydospore formation in Candida albicans. Eukaryot Cell 2, 351-361.

Altschul, S. F., Madden, T. L., Schaffer, A. A., Zhang, J., Zhang, Z., Miller, W. \& Lipman, D. J. (1997). Gapped BLAST and PSI-BLAST: a new generation of protein database search programs. Nucleic Acids Res 25, 3389-3402.
Bahn, Y. S., Kojima, K., Cox, G. M. \& Heitman, J. (2005). Specialization of the HOG pathway and its impact on differentiation and virulence of Cryptococcus neoformans. Mol Biol Cell 16, 2285-2300.

Ballance, D. J. (1986). Sequences important for gene expression in filamentous fungi. Yeast 2, 229-236.

Bell, M., Capone, R., Pashtan, I., Levitzki, A. \& Engelberg, D. (2001). Isolation of hyperactive mutants of the MAPK p38/Hog1 that are independent of MAPK kinase activation. J Biol Chem 276, 25351-25358.

Bilsland, E., Molin, C., Swaminathan, S., Ramne, A. \& Sunnerhagen, P. (2004). Rck1 and Rck2 MAPKAP kinases and the HOG pathway are required for oxidative stress resistance. Mol Microbiol 53, 1743-1756.

Brewster, J. L., de Valoir, T., Dwyer, N. D., Winter, E. \& Gustin, M. C. (1993). An osmosensing signal transduction pathway in yeast. Science 259, 1760-1763.

Causton, H. C., Ren, B., Koh, S. S. \& 7 other authors (2001). Remodeling of yeast genome expression in response to environmental changes. Mol Biol Cell 12, 323-337.

Chen, D., Toone, W. M., Mata, J., Lyne, R., Burns, G., Kivinen, K., Brazma, A., Jones, N. \& Bahler, J. (2003). Global transcriptional responses of fission yeast to environmental stress. Mol Biol Cell 14, 214-229.

Degols, G. \& Russell, P. (1997). Discrete roles of the Spcl kinase and the Atfl transcription factor in the UV response of Schizosaccharomyces pombe. Mol Cell Biol 17, 3356-3363.

Degols, G., Shiozaki, K. \& Russell, P. (1996). Activation and regulation of the Spcl stress-activated protein kinase in Schizosaccharomyces pombe. Mol Cell Biol 16, 2870-2877.

Delgado-Jarana, J., Martinez-Rocha, A. L., Roldan-Rodriguez, R., Roncero, M. I. \& Di Pietro, A. (2005). Fusarium oxysporum G-protein beta subunit Fgb1 regulates hyphal growth, development, and virulence through multiple signalling pathways. Fungal Genet Biol 42, 61-72.

Dixon, K. P., Xu, J. R., Smirnoff, N. \& Talbot, N. J. (1999). Independent signaling pathways regulate cellular turgor during hyperosmotic stress and appressorium-mediated plant infection by Magnaporthe grisea. Plant Cell 11, 2045-2058.

Dumont, F. J. (2000). FK506, an immunosuppressant targeting calcineurin function. Curr Med Chem 7, 731-748.

Fox, D. S., Cruz, M. C., Sia, R. A., Ke, H., Cox, G. M., Cardenas, M. E. \& Heitman, J. (2001). Calcineurin regulatory subunit is essential for virulence and mediates interactions with FKBP12-FK506 in Cryptococcus neoformans. Mol Microbiol 39, 835-849.

Gasch, A. P., Spellman, P. T., Kao, C. M., Carmel-Harel, O., Eisen, M. B., Storz, G., Botstein, D. \& Brown, P. O. (2000). Genomic expression programs in the response of yeast cells to environmental changes. Mol Biol Cell 11, 4241-4257.

Goldman, G. H., Pellizzon, C. H., Marins, M., Mclnerney, J. O. \& Goldman, M. H. S. (1998). Trichoderma spp. genome and gene structure. In Trichoderma and Gliocladium, pp. 209-224. Edited by G. E. Harman \& C. P. Kubicek. London: Taylor \& Francis.

Gustin, M. C., Albertyn, J., Alexander, M. \& Davenport, K. (1998). MAP kinase pathways in the yeast Saccharomyces cerevisiae. Microbiol Mol Biol Rev 62, 1264-1300.

Han, K. H. \& Prade, R. A. (2002). Osmotic stress-coupled maintenance of polar growth in Aspergillus nidulans. Mol Microbiol 43, 1065-1078.

Harman, G. E., Howell, C. R., Viterbo, A., Chet, I. \& Lorito, M. (2004). Trichoderma species - opportunistic, avirulent plant symbionts. Nat Rev Microbiol 2, 43-56.

Hohmann, S. (2002). Osmotic stress signaling and osmoadaptation in yeasts. Microbiol Mol Biol Rev 66, 300-372.

Hohmann, S. \& Mager, W. H. (1997). Yeast Stress Responses. New York: Chapman \& Hall. 
Kawasaki, L., Sanchez, O., Shiozaki, K. \& Aguirre, J. (2002). SakA MAP kinase is involved in stress signal transduction, sexual development and spore viability in Aspergillus nidulans. Mol Microbiol 45, 1153-1163.

Kojima, K., Takano, Y., Yoshimi, A., Tanaka, C., Kikuchi, T. \& Okuno, T. (2004). Fungicide activity through activation of a fungal signalling pathway. Mol Microbiol 53, 1785-1796.

Kothe, G. O. \& Free, S. J. (1998). The isolation and characterization of $n r c-1$ and $n r c-2$, two genes encoding protein kinases that control growth and development in Neurospora crassa. Genetics 149, 117-130.

Kraus, P. R. \& Heitman, J. (2003). Coping with stress: calmodulin and calcineurin in model and pathogenic fungi. Biochem Biophys Res Commun 311, 1151-1157.

Kubicek, G. E. \& Penttila, M. E. (1998). Regulation of production of plant polysaccharide degrading enzymes by Trichoderma. In Trichoderma and Gliocladium, pp. 49-71. Edited by G. E. Harman \& C. P. Kubicek. London: Taylor \& Francis.

Kyriakis, J. M. \& Avruch, J. (2001). Mammalian mitogen-activated protein kinase signal transduction pathways activated by stress and inflammation. Physiol Rev 81, 807-869.

Lawrence, C. L., Botting, C. H., Antrobus, R. \& Coote, P. J. (2004). Evidence of a new role for the high-osmolarity glycerol mitogenactivated protein kinase pathway in yeast: regulating adaptation to citric acid stress. Mol Cell Biol 24, 3307-3323.

Lengeler, K. B., Davidson, R. C., D'Souza, C., Harashima, T., Shen, W. C., Wang, P., Pan, X., Waugh, M. \& Heitman, J. (2000). Signal transduction cascades regulating fungal development and virulence. Microbiol Mol Biol Rev 64, 746-785.

Lev, S., Hadar, R., Amedeo, P., Baker, S. E., Yoder, O. C. \& Horwitz, B. A. (2005). Activation of an AP1-like transcription factor of the maize pathogen Cochliobolus heterostrophus in response to oxidative stress and plant signals. Eukaryot Cell 4, 443-454.

Lewis, J. G., Learmonth, R. P. \& Watson, K. (1995). Induction of heat, freezing and salt tolerance by heat and salt shock in Saccharomyces cerevisiae. Microbiology 141, 687-694.

Lu, Z., Tombolini, R., Woo, S., Zeilinger, S., Lorito, M. \& Jansson, J. K. (2004). In vivo study of Trichoderma-pathogen-plant interactions, using constitutive and inducible green fluorescent protein reporter systems. Appl Environ Microbiol 70, 3073-3081.

Mach, R. L., Schindler, M. \& Kubicek, C. P. (1994). Transformation of Trichoderma reesei based on hygromycin B resistance using homologous expression signals. Curr Genet 25, 567-570.

Maeta, K., Izawa, S. \& Inoue, Y. (2005). Methylglyoxal, a metabolite derived from glycolysis, functions as a signal initiator of the high osmolarity glycerol-mitogen-activated protein kinase cascade and calcineurin/Crz1-mediated pathway in Saccharomyces cerevisiae. J Biol Chem 280, 253-260.

Mendoza-Mendoza, A., Pozo, M. J., Grzegorski, D., Martinez, P., Garcia, J. M., Olmedo-Monfil, V., Cortes, C., Kenerley, C. \& HerreraEstrella, A. (2003). Enhanced biocontrol activity of Trichoderma through inactivation of a mitogen-activated protein kinase. Proc Natl Acad Sci U S A 100, 15965-15970.

Motoyama, T., Ohira, T., Kadokura, K., Ichiishi, A., Fujimura, M., Yamaguchi, I. \& Kudo, T. (2005). An Os-1 family histidine kinase from a filamentous fungus confers fungicide-sensitivity to yeast. Curr Genet 47, 298-306.

Mukherjee, P. K., Latha, J., Hadar, R. \& Horwitz, B. A. (2003). TmkA, a mitogen-activated protein kinase of Trichoderma virens, is involved in biocontrol properties and repression of conidiation in the dark. Eukaryot Cell 2, 446-455.

Park, S. M., Choi, E. S., Kim, M. J., Cha, B. J., Yang, M. S. \& Kim, D. H. (2004). Characterization of HOG1 homologue, CpMK1, from
Cryphonectria parasitica and evidence for hypovirus-mediated perturbation of its phosphorylation in response to hypertonic stress. Mol Microbiol 51, 1267-1277.

Penttila, M. (1998). Heterologous protein production in Trichoderma. In Trichoderma and Gliocladium, pp. 365-382. Edited by G. E. Harman \& C. P. Kubicek. London: Taylor \& Francis.

Penttila, M., Nevalainen, H., Ratto, M., Salminen, E. \& Knowles, J. (1987). A versatile transformation system for the cellulolytic filamentous fungus Trichoderma reesei. Gene 61, 155-164.

Raeder, U. \& Broda, P. (1985). Rapid preparation of DNA from filamentous fungi. Lett Appl Microbiol 1, 17-20.

Reiser, V., Ruis, H. \& Ammerer, G. (1999). Kinase activity-dependent nuclear export opposes stress-induced nuclear accumulation and retention of Hog 1 mitogen-activated protein kinase in the budding yeast Saccharomyces cerevisiae. Mol Biol Cell 10, 1147-1161.

Rep, M., Krantz, M., Thevelein, J. M. \& Hohmann, S. (2000). The transcriptional response of Saccharomyces cerevisiae to osmotic shock. Hotlp and Msn2p/Msn4p are required for the induction of subsets of high osmolarity glycerol pathway-dependent genes. J Biol Chem 275, 8290-8300.

Rey, M., Llobell, A., Monte, E., Scala, F. \& Lorito, M. (2004). Genomics of Trichoderma. In Fungal Genomics: Applied Mycology \& Biotechnology, pp. 225-248. Edited by G. G. Khachatourians. Amsterdam: Elsevier.

Rodriguez-Hernandez, C. J., Sanchez-Perez, I., Gil-Mascarell, R., Rodriguez-Afonso, A., Torres, A., Perona, R. \& Murguia, J. R. (2003). The immunosuppressant FK506 uncovers a positive regulatory crosstalk between the Hog1p and Gcn2p pathways. J Biol Chem 278, 33887-33895.

Roux, P. P. \& Blenis, J. (2004). ERK and p38 MAPK-activated protein kinases: a family of protein kinases with diverse biological functions. Microbiol Mol Biol Rev 68, 320-344.

Sambrook, J. \& Russell, D. W. (2001). Molecular Cloning: a Laboratory Manual. Cold Spring Harbor, New York: Cold Spring Harbor Laboratory.

Sanchez-Perez, I., Rodriguez-Hernandez, C. J., Manguan-Garcia, C., Torres, A., Perona, R. \& Murguia, J. R. (2004). FK506 sensitizes mammalian cells to high osmolarity by modulating p38 MAP kinase activation. Cell Mol Life Sci 61, 700-708.

Shieh, J. C., Wilkinson, M. G., Buck, V., Morgan, B. A., Makino, K. \& Millar, J. B. (1997). The Mcs4 response regulator coordinately controls the stress-activated Wak1-Wis1-Sty1 MAP kinase pathway and fission yeast cell cycle. Genes Dev 11, 1008-1022.

Shiozaki, K. \& Russell, P. (1997). Stress-activated protein kinase pathway in cell cycle control of fission yeast. Methods Enzymol 283, 506-520.

Shitamukai, A., Hirata, D., Sonobe, S. \& Miyakawa, T. (2004). Evidence for antagonistic regulation of cell growth by the calcineurin and high osmolarity glycerol pathways in Saccharomyces cerevisiae. J Biol Chem 279, 3651-3661.

Smith, D. A., Nicholls, S., Morgan, B. A., Brown, A. J. \& Quinn, J. (2004). A conserved stress-activated protein kinase regulates a core stress response in the human pathogen Candida albicans. Mol Biol Cell 15, 4179-4190.

Sousa, S. (2004). Improvement of the Trichoderma harzianum CECT 2413 expression system for the production of proteins with biotechnological value. In Bioquimica Vegetal y Fotosintesis. $\mathrm{PhD}$ thesis, University of Sevilla.

Widmann, C., Gibson, S., Jarpe, M. B. \& Johnson, G. L. (1999). Mitogen-activated protein kinase: conservation of a three-kinase module from yeast to human. Physiol Rev 79, 143-180.

Winkler, A., Arkind, C., Mattison, C. P., Burkholder, A., Knoche, K. \& Ota, I. (2002). Heat stress activates the yeast high-osmolarity glycerol 
mitogen-activated protein kinase pathway, and protein tyrosine phosphatases are essential under heat stress. Eukaryot Cell 1, 163-173.

Yu, V. P. \& Reed, S. I. (2004). Cks1 is dispensable for survival in Saccharomyces cerevisiae. Cell Cycle 3, 1402-1404.

Zeilinger, S., Schmoll, M., Pail, M., Mach, R. L. \& Kubicek, C. P. (2003). Nucleosome transactions on the Hypocrea jecorina
(Trichoderma reesei) cellulase promoter $c b h 2$ associated with cellulase induction. Mol Genet Genomics 270, 46-55.

Zhang, Y., Lamm, R., Pillonel, C., Lam, S. \& Xu, J. R. (2002). Osmoregulation and fungicide resistance: the Neurospora crassa os-2 gene encodes a HOG1 mitogen-activated protein kinase homologue. Appl Environ Microbiol 68, 532-538. 